\title{
ОСОБЕННОСТИ ИСПОЛНЕНИЯ СОНАТ ДЛЯ СКРИПКИ СОЛО И. ХАНДОШКИНА
}

\section{FEATURES OF THE PERFORMANCE OF SONATAS FOR SOLO VIOLIN BY I. KHANDOSHKIN}

\section{Z. Alieva}

Summary: The article is dedicated to the composer and performer Ivan Khandoshkin. The famous Russian virtuoso violinist had a noticeable influence on the formation of the national instrumental style. The article presents a panorama of Russian music of the 18th century. in various forms of its existence. The characteristic features of the emerging national style in the synthesis of European forms, genres and characteristic features of Russian music are determined. Three violin solo sonatas - the pinnacle of Ivan Khandoshkin's virtuoso instrumental style - are viewed as a single microcycle.

In this article, the author proposes the concept of a metacycle of three sonatas by Ivan Khandoshkin for solo violin, united by a series of arched themes. Khandoshkin reformed the principles of development and textured resources, combining the laws of classical and baroque variations, meticulous craftsmanship, imitation of Bach's polyphonic music.

By combining the skills and methods of performance accumulated in violin schools in Germany, Italy and France, Khandoshkin developed his own style of playing and opened up new possibilities for combination. The author comes to the conclusion that in each sonata and in the entire metacycle there is a process of accumulating technical complexity from the beginning to the end of the piece.

Keywords: Khandoshkin, violin, solo, sonata, metacycle, structure, leitmotif, stroke combinations, concept.
Алиева Зарема Эбазеровна

Заслуженный работник образования Республики Крым, Профессор, ГБОУВО РК «Крымский инженернопедагогический университет имени Февзи Якубова»

selsebil@inbox.ru

Аннотация: Статья посвящена композитору и исполнителю Ивану Хандошкину. Знаменитый российский скрипач-виртуоз оказал заметное влияние на формирование национального инструментального стиля. В статье представлена панорама русской музыки XVIII в. в различных формах ее бытования. Определены характерные черты нарождающегося национального стиля в синтезе европейских форм, жанров и характерных особенностей русской музыки. Три скрипичные сольные сонаты - вершина виртуозного инструментального стиля Ивана Хандошкина - рассматриваются как единый микроцикл.

В этой статье автор предлагает концепцию метацикла трех сонат Ивана Хандошкина для скрипки соло, объединенных серией арочных тем. Хандошкин реформирует принципы развития и фактурные ресурсы, сочетая законы классических и барочных вариаций, скрупулезного мастерства, имитации полифонической музыки Баха.

0бъединив, навыки и методы исполнения, накопленные в скрипичных школах Германии, Италии и Франции, Хандошкин разработал свой собственный стиль игры и открыл новые возможности для комбинирования. Автор приходит к выводу, что в каждой сонате и во всем метацикле происходит процесс накопления технической сложности от начала до конца произведения.

Ключевые слова: Хандошкин, скрипка, соло, соната, метацикл, структура, лейтмотив, комбинации штрихов, концепция.

\section{Задачи исследования:}

- Отдельно проанализировать сонаты И. Хандошкина для скрипки соло;

- Проанализировать весь метацикл как комплексную структуру.

Предметом исследования выступает - специфика исполнения сонат И. Хандошкина.

Методология исследования. В данной работе был использован историко-сравнительный и метод комплексного исследования фольклора.

Вариации Хандошкина бросили вызов современным скрипачам, создав ему славу непревзойдённого мастера. Неудивительно, что современники говорили Хандошкину: «Его песни нельзя играть» [1]. 
Смычковая техника Хандошкина так же вызывает интерес. В его вариациях мы находим редкие удары и различные варианты использования стаккато в скрипичной практике 18-го века, особенно тонкие техники рывков.

Русская камерная инструментальная музыка XVIII столетия долгое время оставалась на периферии магистрального пути исследований музыкальной науки. Одна из причин - повышенное внимание историков музыки к музыкальному театру и хоровому концерту, наиболее ярко заявившим о себе в то время. Кроме того, сама форма бытования камерной музыки как прикладного жанра, призванного к увеселению или украшению домашних празднеств аристократии и просвещенных горожан, не способствовала появлению ценных в художественном отношении произведений. Музыка, исполнявшаяся в быту, в основном принадлежала танцевальным жанрам. Непритязательность «пользователей» камерного инструментального жанра оказывала известное влияние на простоту изложения и фактурную безыскусность инструментальных пьес той поры. Велико было значение и русской народной песни. Музыканты-любители и композиторы, владеющие в той или иной степени канонами европейского классического стиля, способами разработки мелодического материала, обрабатывали для заинтересованной аудитории самые разные мелодии русских народных песен и плясок. Публика и музыканты-исполнители охотно включали в свой культурный обиход многообразные инструментальные вариации на народные темы. Тем самым закладывалась важнейшая составляющая национального инструментального стиля. На протяжении десятилетий XVIII в. постепенно, шаг за шагом, шло развитие инструментального исполнительства, одно за другим появлялись произведения русских музыкантов в камерно-инструментальном жанре.

Российские музыканты с огромным интересом изучали инструментарий европейского симфонического оркестра и специфику исполнения на нем. Учились на известных образцах западной музыки, осваивали различные музыкальные формы, включались в общеевропейскую традицию. Это были, как правило, выходцы из социальных низов российского общества, поскольку в XVIII в. светская музыка не воспринималась чем-то серьезным, а лишь служила развлечением или украшением быта. Из крепостных происходил Дегтярев, из солдат - Фомин, из ремесленников - Хандошкин [1, с. 137].

Штриховое разнообразие связано с необычайно богатым ритмом музыки Хандошкина. Это разнообразие проистекает из характера музыкального содержания, а не из внешних навыков исполнителя.

Вариации Хандошкина - максимально насыщенные и законченные произведения русского композитора XVIII века в этом жанре [6].

Важное место в развитии русского национального сольного письма наряду с клавирными сонатами Д. Бортнянского занимают скрипичные сонаты И. Хандошкина $[5]$.

Хандошкин - исполнитель и композитор, привлекающий широкую публику. Итак, другое направление в его стиле игры, импровизация и великолепные концертные выступления, а главное - богатое использование народных песен в его произведениях [5].

В скрипичных сонатах Хандошкина эти типы инструментальной музыки независимы и разнообразны.

Примечательно то, что сонаты по-разному представлены для двух скрипок, сольной скрипки, скрипки и баса. Тематически сонаты Хандошкина не имеют прямого отношения к фольклору. Но широта и мелодичность партии, мягкость и теплота музыки, несомненно, являются результатом благотворных влияний фольклора [7].

Возможно, что «Six sonates a deux violons», изданные в Амстердаме в 1781 году и являющиеся наиболее ранней из известных нам публикаций сочинений Хандошкина, построены на народнопесенных элементах подобно его «русским песням» для двух скрипок [6].

Сольная скрипичная соната Хандошкина, не зависящая от аккомпанемента, подчеркивает выразительную мощь и технические средства скрипки [5]. Поэтому в фактуре преобладают аккорды и двойные ноты. [6].

В этом отличие его сонат от соло для скрипки И.С. Баха. Соната Хандошикина состоит из трех частей. Распределение частей-медленно-быстро-быстро или медленно-быстро-медленно. «В них есть вкус к идеям, темперамент и субъективизм. Великолепная утонченность и риторика уступают место внутреннему значению. Это стиль концертного зала, а не парикмахерской» [6].

Практика домашнего музицирования, исполнения новой музыки русских и зарубежных мастеров постепенно готовила и слушателя к восприятию произведений камерного инструментального жанра самодовлеющей художественной ценности. Медленное и постепенное вхождение в европейскую инструментальную традицию связано еще с одной особенностью русской жизни. Несколько столетий и быт, и повседневную жизнь, и праздники сопровождали народная песня - сольная или ансамблевая и, конечно, хоровая музыка церковных служб. Инструментальная же музыка, звучание европейских оркестровых инструментов долгое время не воспринималось как нечто важное. Такое же отношение было и к русским музыкантам, стремившимся освоить 
выразительные и виртуозные возможности европейского инструментария. До 80-х гг. XVIII в. в кругах русской аристократии в основном пользовалась успехом музыка итальянских композиторов. Первые же образцы русской камерной инструментальной музыки относятся к концу столетия. Эта замечательная музыка связана с именами Дмитрия Бортнянского и Ивана Хандошкина. Именно их творчество заложило основы отечественной камерной инструментальной музыки, принесшей богатейшие плоды уже в XIX и XX веках. Бортнянский и Хандошкин представляют своим искусством как бы два полюса национального камерного стиля. Это стиль галантного утонченного рафинированного искусства Бортнянского и концертный виртуозный демократичный по своим устремлениям стиль Хандошкина. Бортнянский оставил после себя значительное количество сочинений в самых разных жанрах, Хандошкин ограничил себя исключительно скрипичным искусством, но поднял его на почти недосягаемую высоту.

В конце XVIII столетия в обеих русских столицах началась довольно интенсивная концертная жизнь. В дни Великого поста, когда закрывались все театры, наступала пора камерной музыки. Очевидец сообщает в своих записках о 1789 годе: «Никогда еще так много не утешались всеми своими музыками, как в тогдашнее спокойное и приятнейшее в году время. Все они доведены были уже до довольного совершенства, и нам оставалось только или утешаться, чего мы и не упускали делать и нередко музыкантов и певчих доводили даже до усталости. Редкий день проходил, в который бы не доходило у нас до оных дело» [2, с. 68]. Театры открывали свои двери для музыкантов и слушателей камерной музыки. Звучали в основном произведения современных композиторов. За исключением ораторий Генделя, Телемана и некоторых других авторов первой половины XVIII в., репертуар состоял из новой музыки, в том числе и русских композиторов [2, с. 71].

Камерная музыка, отраженная в рукописных сборниках XVIII В., представлена в основном музыкой клавирной. Так же, как и в Европе, семейство клавишных инструментов становится привычным в домашнем музыкальном обиходе России. К концу столетия молоточковое фортепиано вытесняет клавикорд. Клавирные сонаты Дмитрия Бортнянского были написаны уже для нового инструмента. Певучий звук фортепиано как нельзя лучше вписался в национальный инструментальный стиль, изначально тяготевший к русской песне. Еще более естественным оказался звук скрипки, способный со свойственной ей теплотой передать дух народной песни. Скрипка включалась в то время в самые разные составы камерных ансамблей. Можно с уверенностью сказать, что великая русская симфоническая традиция имела своим началом камерную инструментальную му- зыку XVIII века. Его прообразом стала музыка, написанная и исполнявшаяся ансамблями, включавшими в себя европейские оркестровые инструменты, среди которых скрипка, как правило, играла главенствующую роль.

Большое значение для формирования русского скрипичного исполнительства имели итальянские музыканты: Джованни Веронаи, Луиджи Мадонис, Доменико Далольо, Антонио Лолли, Джузеппе Виотти, Джузеппе Тартини. Последний оказал заметное влияние на выдающегося композитора эпохи Ивана Хандошкина. Так, М.Р. Габдуллин отмечает наиболее существенные аспекты воздействия итальянского скрипача и композитора на искусство своего русского коллеги - это «тяготение к итальянскому стилю concitato (в частности, использование диссонирующих интервалов); опора на особенности оперного речитатива; воплощение специфики оперного стиля lamento; передача вокальной природы народной мелодики; балансирование между четкой структурной организацией (с глубокими контрастами разделов) и сквозным развитием; расширение технических возможностей правой руки (обогащение штрихов)» [3, с. 97].

Иван Хандошкин, названный современниками «Нашим Орфеем», всецело посвятил себя камерному инструментальному жанру. Как и другие композиторы того времени, он писал музыку в основном в форме вариаций. Его трактовка жанра выходит далеко за пределы обихода домашнего музицирования. Самое масштабное сочинение в форме вариаций - 40 вариаций на тему песни «Калинушка». По масштабу это сочинение можно сравнить лишь с тарти-ниевским «Искусством смычка». Автор монографического очерка о Хандошкине Г.Ф. Фесечко называет вариационный цикл композитора «энциклопедией разнообразных приемов вариационной разработки русских народных песен» [4, с. 62]. Техническая изобретательность автора никогда не противоречит духу русской песни, положенной в основу вариаций. «Хандошкина как композитора вариаций, - пишет В.А. Цуккерман, - отличает прежде всего искусство сохранять дух темы в любых, даже самых развитых и оживленных ее преобразованиях; интонации темы почти всегда сквозят через ткань вариаций. Поразительны свобода рисунка, живость и разнообразие ритмики. В вариациях Хандошкина фигурация служит композитору, а не он ей» [5, c. 237].

Его совершенное владение скрипкой стало главным подспорьем масштабного виртуозного стиля как во множестве вариаций на русские темы, нескольких дуэтах для струнных инструментов, так и в трех сольных скрипичных сонатах. Фактура этих сочинений не просто сложна, а изощренна. Она изобилует самыми разными виртуозными приемами и штрихами, полна аккордовой техникой и изобилием двойных нот. Как известно, жанр соль- 
ной скрипичной сонаты достиг своего расцвета в эпоху барокко, особенно в творчестве И.С. Баха. Хандошкин, хорошо знакомый с европейской традицией, прежде всего с музыкой итальянцев, создает, однако, свои сочинения в этом жанре на совершенно иных основаниях, нежели европейские мастера. Был ли знаком Хандошкин с сольными скрипичными сонатами Баха, доподлинно неизвестно. Из немецких композиторов наиболее близок Хандошкину почти не исполняющийся сегодня, а в то время достаточно известный немецкий композитор Вильгельм Фридрих Руст. Скрипичные сольные сонаты и немецкого, и русского композиторов основываются на старинной сонате, но в некоторых чертах приближаются к сонатной форме венских классиков. Ю.В. Келдыш считает, что Хандошкин «культивирует форму скрипичной сонаты соло в последних десятилетиях XVIII века, когда на Западе она была уже почти забыта и вышла из творческого обихода композиторов» [6, с. 107]. Сонаты Хандошкина заимствуют форму старинной сонаты-сюиты от итальянцев. Но в своем творчестве он идет дальше: развивает мелодику и фактуру. Хандошкин почти не прибегает к использованию полифонических приемов. Фактура его скрипичных сонат, за редким исключением, гомофонна. И. Ямпольский в этом видит принципиальное отличие от скрипичных сочинений Баха: «...применяя аккорды и двойные ноты, достигая разнообразия и полноты звучания, Хандошкин остается в рамках чисто гомофонного стиля. В этом - отличие его сонат от сонат и партит И.С. Баха для скрипки соло» [7]. Наличие разработки и репризы сонатного allegro в сонате соль минор сближает форму с классическим каноном сонаты. Стройная архитектоника скрипичных сонат Хандошкина - одно из их неоспоримых достоинств. По мнению Г.Ф. Фесечко, «Хандошкин обнаруживает не только композиторское мастерство в отношении преобразования тематизма и тематического развития, но и замечательное чувство музыкальной формы в целом» [4, с. 64].

В скрипичных сонатах Хандошкин обнаруживает редкую изобретательность в использовании приемов различных предшествующих, современных и только нарождающихся стилей. С.И. Нестеров так пишет об этом свойстве композитора Хандошкина: «Он ни разу не повторяется в структуре цикла, свободно комбинирует части классических сонат и сюит, церковной сонаты и барочной партиты, вариаций. Все три сонаты для скрипки соло представляют собой метацикл из трех циклических образований, что подтверждают прямые тематические связи первой и третьей сонаты. Третья соната композиционно неустойчива. И равновесие формы поддерживается ее только «репризностью» по отношению к первой сонате. Во всех сонатах есть вариации, в которых использованы орнаментальные классические модели. Композитор использует виртуозные приемы игры на скрипке, идущие преимущественно от Моцарта и Тарти- ни. Это обеспечивает синтез в его творчестве барочных и классических тенденций. Возникает диалог стилей.» [4, с. 9].

По тому, сколько много технических приемов и трудностей встречается в сонатах для скрипки соло, можно судить и о техническом мастерстве автора, и о скрипичном исполнительстве того времени. Еще до явления на европейской сцене великого Никколо Паганини Иван Хандошкин потрясал своих слушателей своим искусством концертного скрипача. Очевидец пишет: «при неописуемо смелых скачках и пассажах, какие он с истинно русской удалью исполнял на своей скрипке, так ноги слушателей и слушательниц сами собой начинали невольно подпрыгивать» [7, с. 33]. Хандошкин играл и на одной струне, и на перестроенном инструменте. Примечателен текст объявления в «Санкт-Петербургских ведомостях» о концерте, в котором надлежало играть русскому виртуозу: «В четверток 12 числа сего месяца, на здешнем немецком театре будет дан музыкальный концерт, в котором г. Хандошкин играть будет соло на расстроенной скрипице» [7, с. 33]. И. Ямпольский считает, что «широкое использование Хандошкиным приема скордатуры характерно для связей его исполнительского искусства с искусством народных скрипачей. Скордатура, прием, обычный для народного скрипача, беспрестанно изменяющего строй скрипки в соответствии с тональностью исполняемой песни. Благодаря этому приему скрипач получает возможность, не выходя за пределы первой позиции, извлекать из своего инструмента сочетания звуков, которые при нормальном строе извлечь невозможно» [6]. Игра мастера была не только головокружительно виртуозна, но и чрезвычайно проникновенна в певучей музыке. «Слушая «Адажио» Хандошкина, никто не в силах был удержаться от слез», -свидетельствует слушатель [7, с. 34]. Музыкант не чурался в ярмарочный день выйти на площадь и играть перед простым людом. Может, еще и поэтому его стиль называют концертным, он стал как бы предчувствием широкой демократизации музыкального искусства, предощущением того времени, когда музыка высокой традиции выйдет из дворцов и аристократических гостиных и станет достоянием многих.

Каждая из сольных скрипичных сонат представляет собой маленький шедевр. Они образуют и некое подобие цикла, объединяясь тематическими или мотивными связями. Строение их идентично некоторым образцам раннеклас-сического стиля. Это медленная первая часть, менуэт с трио или сонатное allegro второй части и стремительный финал с некоторыми чертами весьма подвижного характерного танца.

Первая соната соль-минор выделяется исследователями как безусловный шедевр национального камерно- 
инструментального искусства. В ней, наряду с обилием ярчайших проявлений концертно-виртуозного стиля, можно отметить и монументальность формы, и напряженность патетического высказывания, и тонкость лирических тем. Ее начало - редкий в жанре сольной скрипичной сонаты траурный марш. Его иногда называют маршем-эпитафией за рельефную речитативную выразительность интонации. Музыка здесь почти буквально подражает патетической речевой декламации. Так много здесь контрастной громкостной динамики, мелких мотивных делений фразы, самых разных штрихов, много кратких экспрессивных усилений и пассивных затуханий звука. Есть здесь и некоторые черты диалога. Он проявляется и в параллельном движении нижнего голоса, и в ответах «баска» на патетические возгласы темы (Рис. 1).

Стремительная вторая часть написана в форме сонатного allegro. Здесь можно усмотреть связь как со старинной сонатной формой, так и с раннеклассической сонатой. Заметны здесь и элементы двухтемности. Непрестанное движение восьмых в очень быстром темпе прерывается речитативными реминисценциями и ка- денциями, предусмотренными автором как импровизации солиста (Рис. 2).

Финал сонаты представляет собой вариации на песенную тему печально-элегического характера. Музыка темы финала связана с темой траурного марша первой части. Шесть последующих вариаций являют динамизацию темы. Каждая новая вариация вместе с тематическим развитием вносит новые фактурные решения, сопровождаемые усложнением приемов скрипичной игры. Принято считать, что финал первой скрипичной сонаты Хандошкина - один из самых трудноисполнимых опусов во всей скрипичной литературе (Рис. 3).

Вторая соната Си-бемоль мажор написана в моцартовском духе. Автор, как и в других своих сочинениях, вкладывает в европейскую классическую форму характерную напевность русской народной песни. Изысканность мелодического рисунка, слегка украшенного прихотливой орнаментикой группетто, мордентов и форшлагов, галантные завершения мотивов отнюдь не мешают проявлению русского мелоса (Рис. 4).

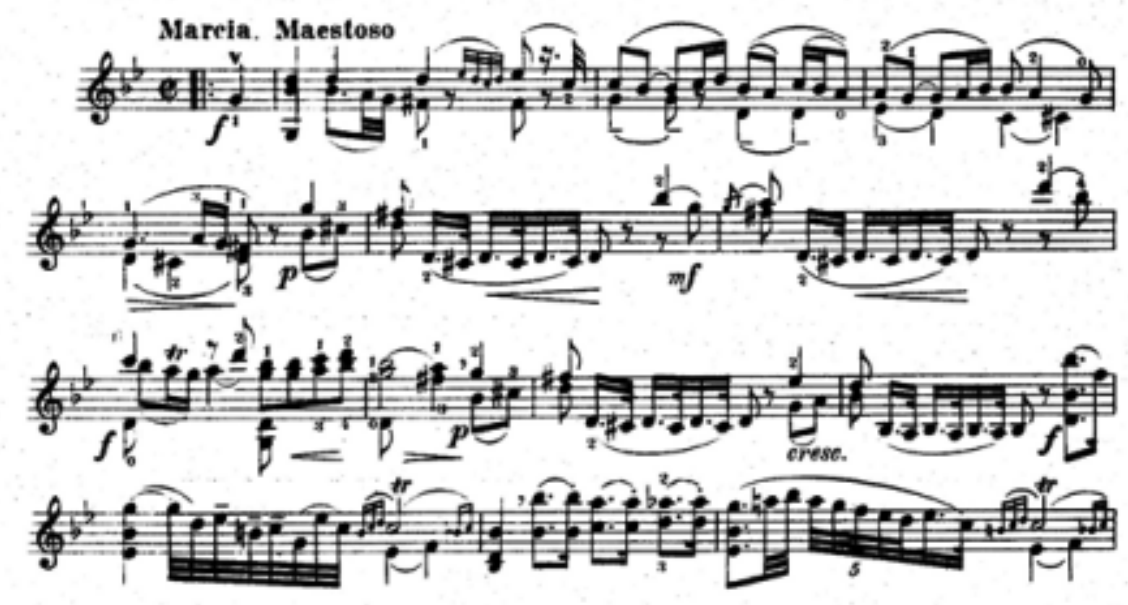

Рис. 1.

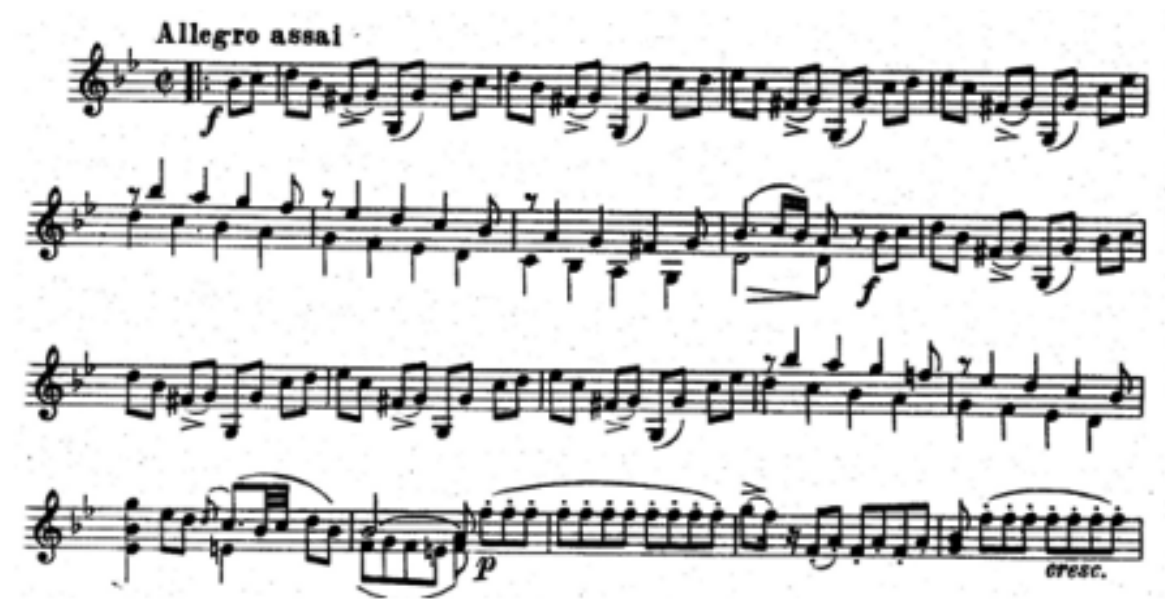

Рис. 2 


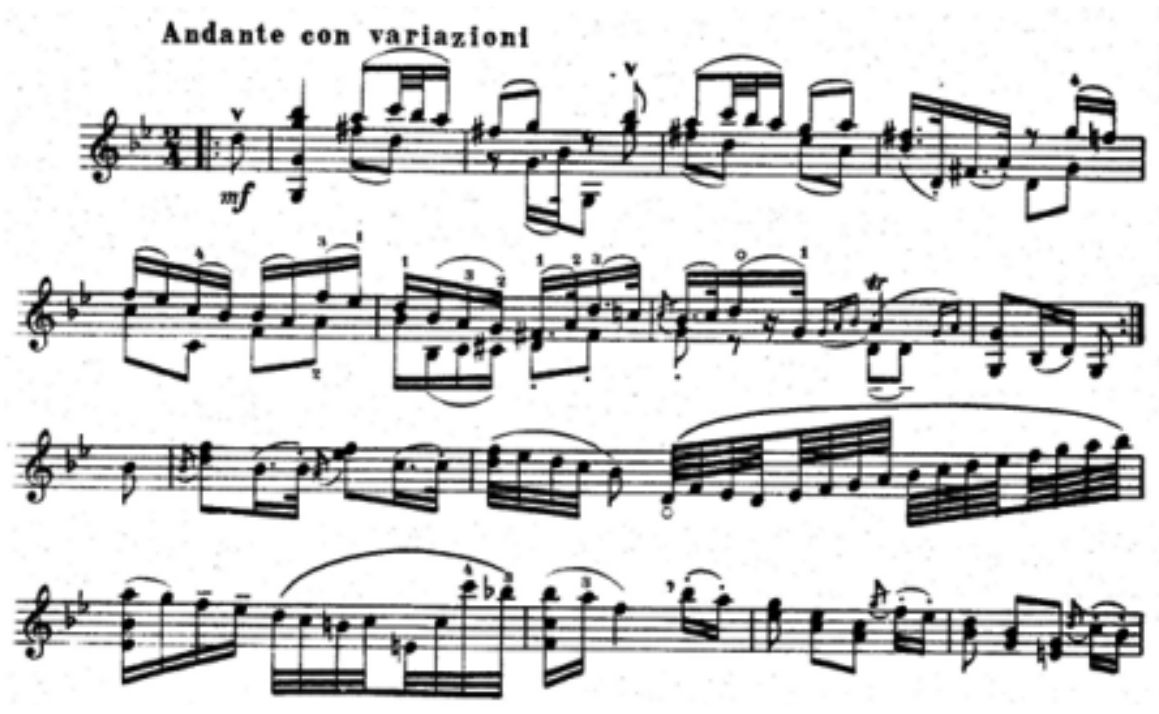

Рис. 3.

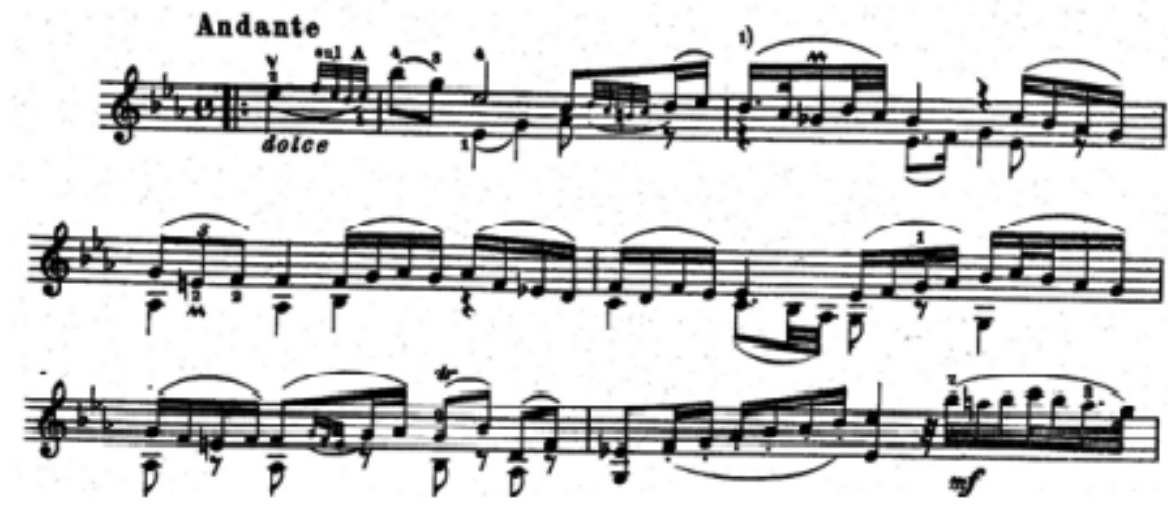

Рис. 4.
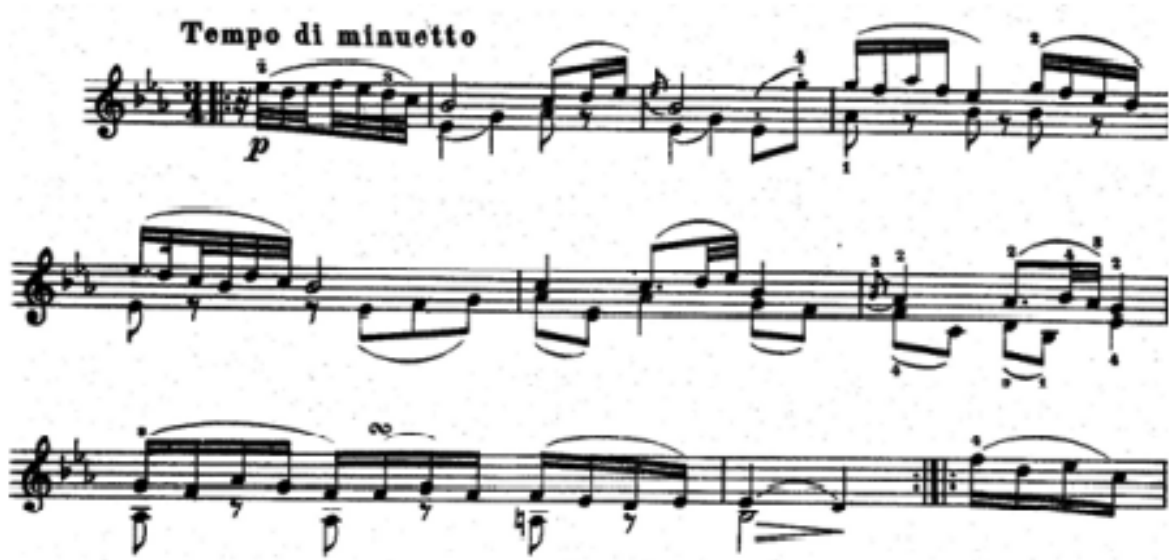

Рис. 5.

Менуэт второй части несет в себе и черты галантного придворного танца, и патетического речитативного высказывания, и всепроникающего песенного начала
(Рис. 5).

Трио менуэта приводит с собой «тень» минорного лада. Автор следует по разным тональностям, неизмен- 


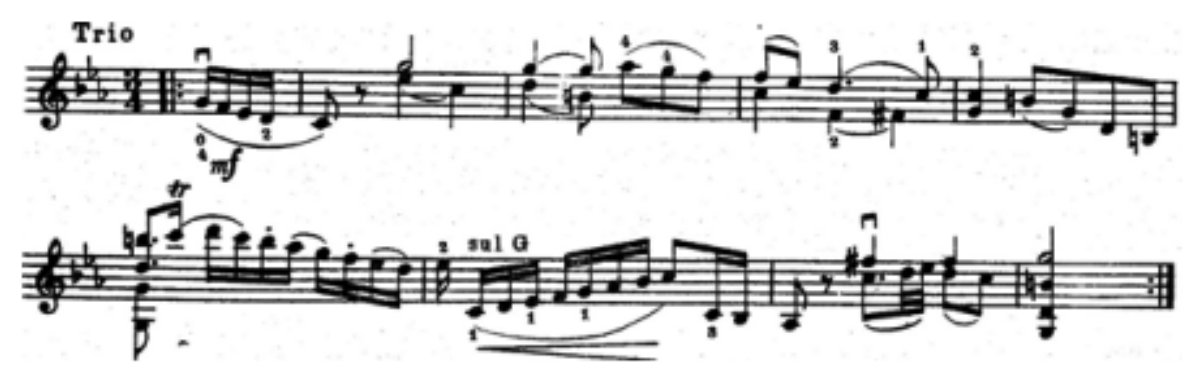

Pис. 6.

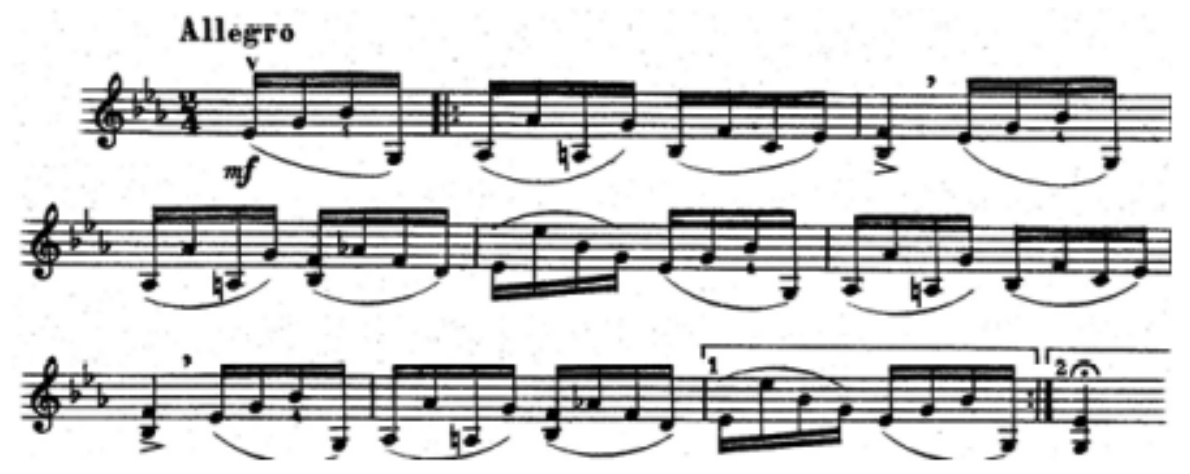

Pис. 7.

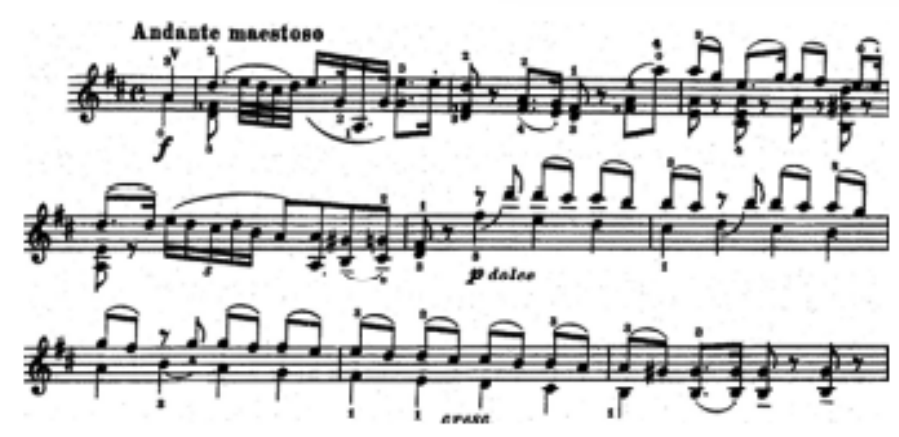

Рис. 8.

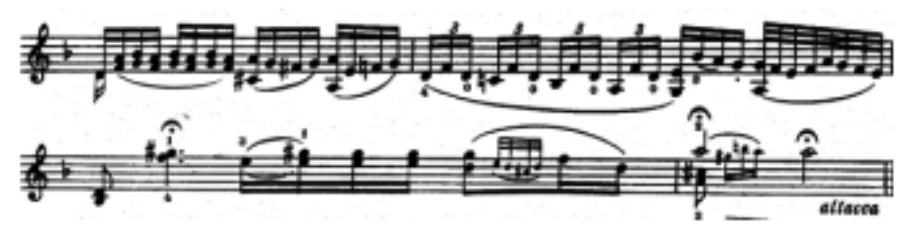

Рис. 9.

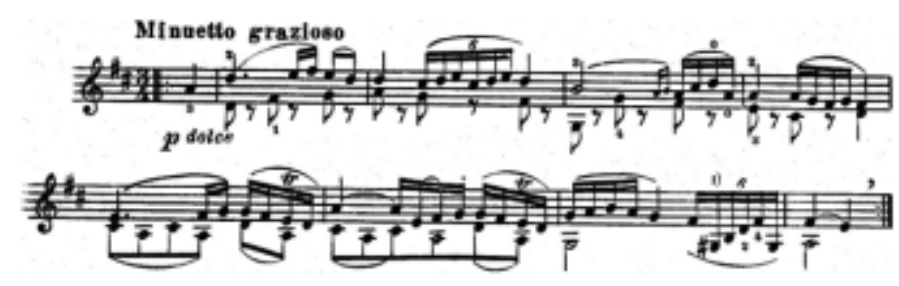

Рис. 10. 


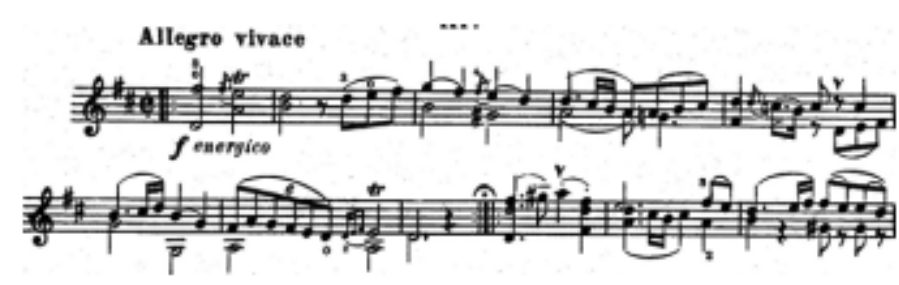

Рис. 11.

но держась минорного оттенка в гармонии, и завершает менуэт все в том же параллельном основной тональности до миноре (Рис. 6).

Моторное финальное рондо, по выражению И. Ямпольского, своеобразно преломляет идею «перпетууммобильности» [7]. Явно слышны здесь и отголоски народной пляски. На память приходят и некоторые «колена» Камаринской (Рис. 7).

Ремарка Maestoso, предпосланная первой части третьей сонаты, относит нас к Сонате № 1 соль минор, к ее траурному маршу. Но мажорный лад и общий светлый колорит этой музыки говорят об абсолютно противоположном образе. Есть, правда, некоторое сходство в довольно заметном разговоре будто двух персонажей, один из которых ведет пространную речь, другой сопровождает. Так же, как и в траурном марше, есть некий «собеседник» темы, отвечающей краткими репликами. Начало темы с доминантового звука к тонике по-своему оппонирует подобному затакту марша первой сонаты, где горестный вопрос «задается» от тонического звука к доминантовому (Рис. 8).

Завершается первая часть эпизодом в манере органной токкаты в одноименном минорном ладу. Здесь автор, отмечая два места ферматами, предполагает каденции солиста. Можно только предполагать, с каким искусством импровизировал сам Хандошкин в этих местах (Рис. 9).

Без перерыва attacca вступает грациозный менуэт второй части сонаты. И здесь, так же как в менуэте Мибемоль мажорной сонаты, галантность соединяется с напевностью, так свойственной многим народным темам (Рис. 10).

Венчает весь цикл лаконичный финал. Его отличает смелая виртуозность, изобилие разнообразнейших приемов на такой короткой «дистанции», энергичные аккорды и головоломные броски пассажей с использованием и staccato, и legato, грация мелких мотивов, собранных «певучей» линией фразы. Роль второго «скрипача» в дуэте более заметна, чем ранее (Рис. 11).

И здесь перед финальным проведением темы Хан- дошкин ставит фермату на «ля» малой октавы, как бы приглашая скрипача-виртуоза высказаться в каденции, в импровизации выразить свое отношение к этой прекрасной, яркой и вместе с тем тонкой и чрезвычайно обаятельной музыке.

В сонатах для скрипки соло Иван Хандошкин явил себя как выдающийся композитор эпохи, обладающий своим узнаваемым лицом; явил себя и как недюжинный и редкий тип исполнителя-виртуоза. И в том, и в другом роде профессиональной деятельности он обогатил русскую музыку и в своих произведениях. В исполнительском искусстве открыл богатейшие ресурсы русской народной песни, показал универсальные возможности европейских музыкальных форм и способов разработки материала на поле национального русского мелоса, ввел некоторые черты народного певческого искусства (такие как подголосочная полифония) в ткань своих сочинений. Великий русский симфонизм и камерная инструментальная музыка последующих эпох опираются на прекрасные образцы камерного жанра конца XVIII столетия, заложившие прочные основы русского национального стиля, на произведения мастеров, до сегодняшнего дня сохранивших свою оригинальность и свежесть музыкальной мысли. Среди музыкантов той поры имя Ивана Хандошкина занимает одно из важных и почетных мест.

Bo всех произведениях композитора Хандошкина мы видим воплощение самобытной личности русских художников, своеобразие музыкального мышления, выраженное через неповторимую национальную интерпретацию скрипки. Хандошкин заимствовал художественные традиции народного творчества, развил и обогатил скрипичную технику, создал законченный образец русской скрипичной музыки XVIII века [7].

\section{Выво $\triangle$ b}

Иван Евстафьевич Хандошкин - основоположник русского скрипичного исполнительства. Талантливый музыкант - самоучка.

Хандошкин одним из первых использовал и блестяще обработал русские крестьянские и городские народные песни в своих произведениях для скрипки и других 
инструментов. Он приобрел известность и как собиратель народных песен. Имя Хандошкина было популярно в России. Талантливый композитор, с ярко выраженным национальным складом дарования, создатель русской скрипичной литературы и один из основоположников русского скрипичного стиля, блестящий скрипач, виртуозно владевший игрой на гитаре и балалайке, дирижер и педагог - таков разносторонний круг деятельности это- го замечательного творца.

В произведениях композитора Хандошкина сохранен весенний колорит русской народной музыкальной культуры. Несомненно, этот великий русский скрипач не одинок в своем первоначальном поиске. Возможно, дальнейшие исследования откроют много неизвестных скрипичных произведений забытых мастеров, окружавших этого выдающегося деятеля искусства.

\section{ЛИТЕРАТУРА}

1. Гинзбург Л., Григорьев В. История скрипичного искусства. Вып.1. М.: Музыка. 1990. 348 с.

2. История русской музыки: в 10 т. М.: Музыка. 1985. Т. 3.424 с.

3. Калошина Г. Проблемы драматургии и цикла в симфониях Г. Канчели // Памяти учителей: А. Сохор и Л. Хинчин. Ростов-н/Д: РГК им. С.В. Рахманинова. 1996. С. 48-64.

4. Калошина Г. Проблема концепции и становление «интонационной фабулы» в поздних симфониях Антона Брукнера // Южно-Российский музыкальный альманах. Ростов-н/Д: РГК им. С.В. Рахманинова. 2006. С. 159-168.

5. Левашова 0., Келдыш Ю., Кандинский А. История русской музыки. Т. 1. изд. 3-е. М.: Музыка. 1972.506 с.

6. Паукнер Е. Русское скрипичное искусство последней трети XVIII века и деятельность И. Хандошкина: автореф. ... канд. иск. Ростов-н/Д: РГК. 2013.25 с.

7. Я Ямпольский И. Русское скрипичное искусство. Очерки и материалы. М., Л.: Музгиз. 1951. 515 с.

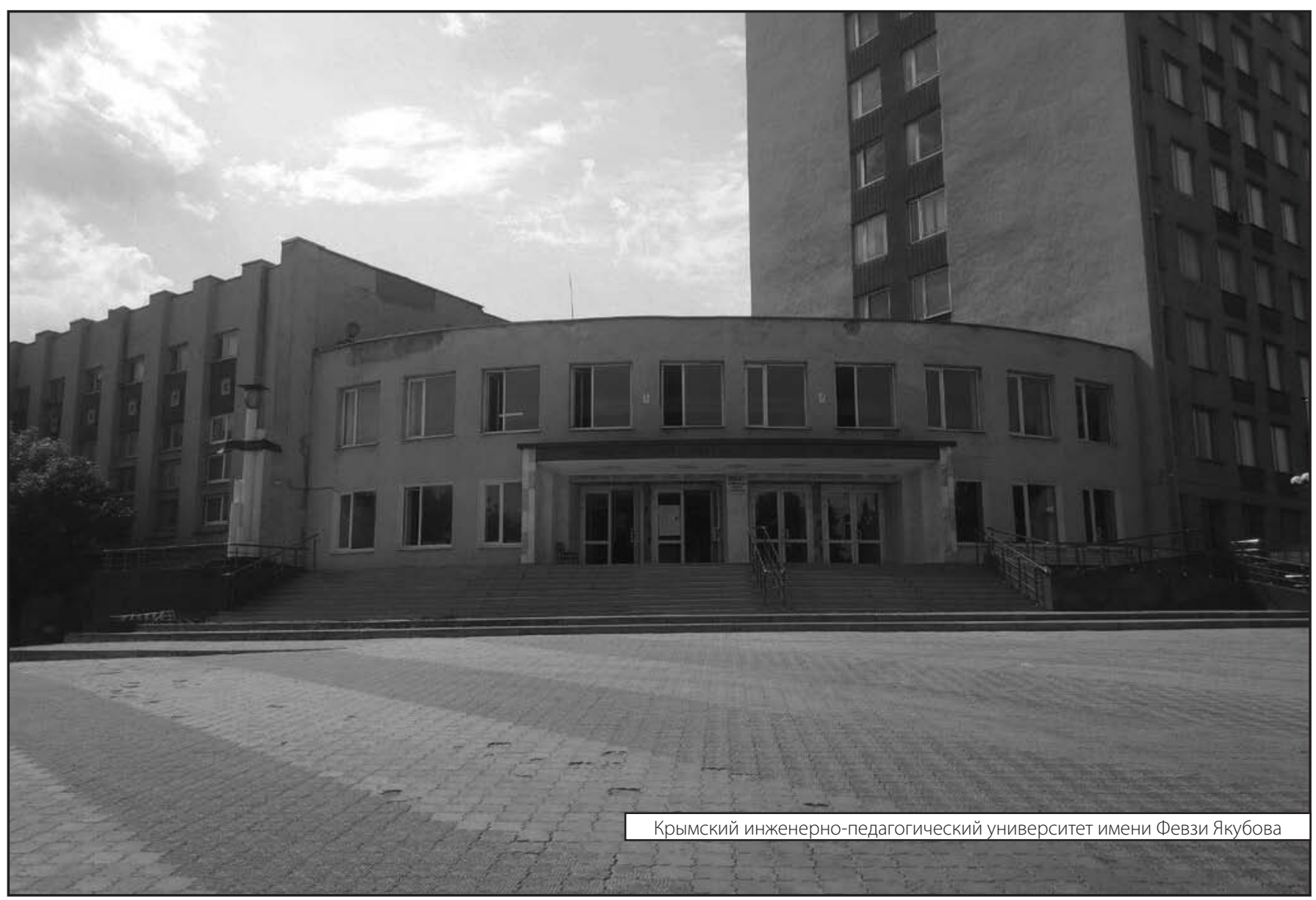

